\title{
Impact of Covid-19 Pandemic on Food Consumption in Indonesia
}

\author{
Amalia Zaida \\ Master of Public Health Program, Faculty of Public Health, Muhammadiyah University of Jakarta \\ K.H. Ahmad Dahlan, Cireundeu, Ciputat, Jakarta Selatan, 15419 \\ E-mail : zaidaamalia@yahoo.co.id
}

\begin{abstract}
Prevention of Covid-19 transmission by increasing immunity of the body with protein intake results in changes in people's dietary behavior. Pressure due to changing environment and loss of work leads to the tendency to eat sweet foods, preserved, high in fat and salt. This study aims to determine changes in food consumption patterns in Indonesia during the Covid-19 pandemic. Use a quick assessment of empirical facts about Indonesia's ongoing impact on Covid-19. The research approach framework conceptualizes Covid-19 as a 'Cause', and its effect on changes in food consumption patterns is "Consequent". The data used in this study from study literature uses references from national and international literature. Literature materials in the form of journals, articles, books, and news that discuss the impact of the Covid-19 pandemic on people's behavior, especially food consumption behavior, which can be accessed in electronic media. Pandemic covid-19 in Indonesian society affects food consumption patterns, namely, in adults, consumption of vegetables, fruits, and spices increases. While in adolescence, consumption of sweets and fast food increases. This change in the diet affects immunity. A healthy diet increases immunity and reduces the potential for contracting covid-19. Changes in different diets require a tailored approach to community nutrition fulfillment programs. It is necessary to create a program to raise awareness among young people to implement a healthy diet, and a program to support the consistency of healthy diets that have been formed in the community due to the covid-19 pandemic.
\end{abstract}

Keywords: Food consumption behavior, Covid-19 pandemic 


\section{INTRODUCTION}

The World Health Organization (WHO) has declared COVID-19 as a Global Pandemic on March 11, 2020. To control the spread of covid-19, many countries impose restrictions on activities. The impact of pandemics and restrictions on activity is the change in shopping behavior and diet in the community as one of the psychological effects. Studies have shown that stressors such as pandemic-related income loss can cause a tendency to "eat comfortably" as the vent. Fears of infection can also lead to less shopping and purchases of food with a longer shelf life/preserved food (Robertson Sally 2021).

In addition to the efforts of government institutions to prevent the spread of Covid-19 by issuing a policy of restricting activities, which in Indonesia is known as Large-Scale Social Restrictions (PSBB), the public must also play an active role in efforts to counter the transmission and spread of Covid-19. This community participation can be realized, among others, by complying with the government's Covid-19 prevention policy, as well as conditioning itself so that it is not easily infected and transmitting Covid-19. One way to prevent contracting Covid-19 is by increasing immunity.

To increase immunity the body needs to increase protein intake more than usual, but the addition of this protein should not increase the amount of energy. The principle in improving endurance is to maintain a normal weight, maintain a diverse food intake so that it can intake a variety of nutrients. Various macronutrients and micronutrients, in the body, will work together in harmony to keep the body from infection attacks (Sumarmi 2020)

The phenomenon of changing food consumption patterns of Indonesian people is interesting to observe, because, in contrast to research conducted by some researchers in other countries, such as in Italy, Germany, Qatar, and Latin America, it turns out that the changes that occur in each country are not the same pattern. And based on research from Azrimaidaliza et al, there is no significant relationship between knowledge and attitudes with respondents' behavior regarding COVID-19 and prevention efforts, especially in improving immunity. Although respondents' knowledge belongs to the good category, there are still those who behave badly in efforts to prevent Covid-19, in this case, it means not complying with the recommendations of health protocols from the government. Is it true that there was a change in food consumption patterns in Indonesia during the Covid-19 pandemic? Do the changes have a positive or negative effect on the transmission and spread of Covid-19?

\section{METHODS}

The research methodology uses a quick assessment method of empirical facts about the ongoing impact of Covid-19 in Indonesia. The research approach framework conceptualizes that 
E-ISSN: 2808-5361

http://e-journal.fkmumj.ac.id/
Proceeding The First

Muhammadiyah

Internasional- Public Health

and Medicine Conference

Covid-19 is a 'Cause', and its negative effect on changes in food consumption patterns is "Consequent".

The data used in this study is the result of study literature using references from national and international. Literature materials in the form of journals, articles, books, and news that discuss the impact of the Covid-19 pandemic on people's behavior, especially on food consumption behavior, which can be accessed in electronic media, and news published in electronic media.

\section{RESULTS AND DISCUSSION}

The World Health Organization (WHO has declared COVID-19 as a Global Pandemic on March 11, 2020. The Covid-19 pandemic has not only an impact on health problems but also humanitarian issues that impact the social, economic, and economic aspects of the country. Almost all countries in the world experience it, including Indonesia. On April 13, 2020, the Presidential Decree of the Republic of Indonesia No. 12 of 2020 concerning the Determination of Non-natural Disasters spreading Corona Virus Disease, declared the Covid-19 Pandemic as a non-natural disaster caused by the spread of Corona Virus Disease 2019 COVID-19 as a national disaster.

To prevent the spread of the Covid-19 pandemic, some countries have implemented largescale public and social health measures (Langkah Kesehatan Masyarakat dan Sosial), such as restrictions on movement, restrictions of schools and businesses, quarantine of geographic areas, and travel restrictions. These measures are known as "lockdown" or "shutdown" (Junaidi 2020). Lockdown on a limited scale was first implemented in Indonesia on March 31, 2020, based on the implementation of PP No. 21/2020 on Large-Scale Social Restrictions in Accelerating the Handling of Covid-19.

In addition to the efforts of government institutions to prevent the spread of Covid-19 by issuing PSBB policies, the public must also play an active role in efforts to counter the transmission and spread of Covid-19. This community participation can be realized, among others, by complying with the government's Covid-19 prevention policy, as well as conditioning itself so that it is not easily infected and transmitting Covid-19. One way to prevent contracting Covid-19 is by increasing immunity.

Immunity of the body, which is a system to fight foreign bodies that enter the body that can interfere with health, is the body's resistance to diseases, especially infectious diseases. The defense of the body consists of several layers. The outermost defense is called innate immunity, and the next defense is adaptive immunity, which is a type of body defense to deal with microorganisms that successfully penetrate body tissues. Natural immunity plays a role to inhibit the entry of bad microorganisms and expelling those that successfully enter the tissues quickly. Natural immune components in the form of epithelial cells will block the entry of microorganisms. And if 
microorganisms in the form of bacteria or viruses successfully penetrate the tissues and enter the blood circulation, they will be attacked by phagocyte cells consisting of Natural Killer cells and a special protein called a complement system.

The adaptive immune system is slower, takes longer to form, but is more effective in fighting infections. The adaptive immune system is antibody-shaped, produced by B-cell lymphocytes and proteins produced by lymphocyte $\mathrm{T}$ cells. Antibodies are part of a protein called immunoglobulin, located in the circulation of blood and mucosal fluid, serves to bind and neutralize bacteria and viruses that are outside the cell (extracellular).

To increase immunity the body needs to increase protein intake more than usual, but the addition of this protein shouldn't increase the amount of energy. The principle in improving endurance is to maintain a normal weight, maintain a diverse food intake so that it can intake a variety of nutrients. Various macronutrients and micronutrients, in the body, will work together in harmony to keep the body from infection attacks (Sumarmi 2020).

Various conditions that occur during the COVID-19 pandemic affect society, both psychologically, physically, economically, and socially, because the Covid-19 pandemic is a severe stressor. Anxiety is a common response that occurs during times of crisis. Anxiety is a common condition of fear or discomfort that is often characterized by a variety of symptoms, which include physical, behavioral, and cognitive symptoms.

Anxiety or stress is one of the psychological disorders that can decrease the strength level of a person's immune system. One of the stress effects that can decrease the immune system is the release of many stress hormones called cortisol which if it comes out too much and occurs continuously will have an impact on a person's immune system (Wakhudin et al. 2020). Whereas in the current pandemic, immunity is one of the main weapons in the fight against Covid-19.

Other impacts of pandemics and restrictions on this activity include changes in shopping behavior and diet. Studies have shown that pressures such as pandemic-related income loss can lead to a tendency to "eat comfortably"-i.e. eating sugary foods, high in fat and salt, as the vent. Fears of infection can also lead to less frequent shopping and purchases of food with a longer shelf life/ preserved food.

Research on dietary behavior changes has been conducted in various countries. The survey conducted by Adriano Profeta of the German Institute of Food Technologies in Germany also showed that consumption of alcohol and sweets has increased during the pandemic. In contrast, fruit and vegetable intake had decreased (Robertson Sally 2021). In Latin American countries, there is a high frequency of consumption of ultra-processed foods among adolescents, which is also exacerbated by the enforcement of restrictions on activities or lockdown (Belén Ruíz-Roso et al. 2020). Furthermore, these findings reveal that families who experience loss of income as a result of the pandemic adopt 
more of these unhealthy habits. In Italy, research conducted by Federico Scarmozzino and Francesco Visioli obtained the same results, that food consumption patterns tend to adopt the type of "comfort food" (Scarmozzino and Visioli 2020). In contrast, research conducted in Qatar by Tarek Bin Hassen et al in his journal Impact Of Covid-19 On Food Behavior And Consumption In Qatar, suggests a tendency to increase awareness of healthy food consumption and health in general. Qataris tend to reduce the consumption of unhealthy foods, such as junk food, unhealthy snacks, sweets, and pastries, and prefer to eat healthier foods, such as fruits and vegetables, and drink more water (ben Hassen, El Bilali, and S Allahyari 2020).

Food consumption is influenced by several factors such as income level, food availability, public awareness of nutrition, and socio-cultural factors. In the research conducted by Rahmadya Saputri et al in Riau, there are still many households whose food consumption patterns are not met and the consumption of protein is less, due to the low consumption of food from respondents, in addition, there is also no diversity of food types and low consumption of food, especially protein source foods (Saputri, Lestari, and Susilo 2016).

Table 4. Model yang Berpengaruh Paling Dominan terhadap Tingkat Ketahanan Pangan berdasarkan Model Analisis Regresi Logistik

\begin{tabular}{lc}
\hline \multirow{2}{*}{ VARIABLE } & FOOD SECURITY \\
\cline { 2 - 2 } & TYPE \\
Consumption Patterns & $(\mathbf{9 5 \%} \mathbf{C I})$ \\
Unfulfilled & $7,57^{*}(1,82-31,04)$ \\
Fulfilled & \\
Protein Consumption & \\
Less & $7,51(1,89-30,59)$ \\
Good & 105 \\
$\mathrm{~N}$ & 0,416 \\
$\mathrm{R}^{2}$ & 40,97 \\
Deviance-2log likelihood & \\
\hline
\end{tabular}

*Signifikan $(\mathrm{p}<0,05)$

Based on Miranti et al's research, households in urban areas consume a lot of food for the finished food and beverage group, while rural households consume more grain groups. Changes in food income and prices do not significantly affect food demand for households in West Java Province (Miranti and Syaukat 2016).

In Mayasari et al research, it was found that household consumption patterns in low/moderate HDI (Human Development Index) and high/very high HDI areas differed, in addressing changes in price and income. Finished food commodities/cigarettes are increasingly dominant, both in the low / medium HDI area and in the high / very high HDI area. Rice/tubers are still a basic necessity for most 
households in East Java, especially in low/moderate HDI areas. While meat/fish/milk/eggs is a luxury commodity for most households in East Java (Mayasari, Satria, and Noor 2018)

Research conducted by Saragih et al in Indonesia with respondents are civil servants / TNI as many as 82 people (41\%), then students as many as 54 people (27\%) and private employees as many as 31 people $(15.5 \%)$ indicates a change in dietary consumption patterns. There is an increase in the diversity of food consumption. The increase in food diversity analyzed occurs due to the desire to have better nutrition and support to increase immunity or endurance. As many as $76 \%$ of respondents tend to make empon-empon (spice) as a drink during the covid-19 pandemic. One of the contributing to increase public awareness of the importance of good nutrition is the media that conveys that one of the antidotes to the covid-19 virus is to increase immunity or body immunity. And the diversity of food consumed by eating will increase the source of nutrients obtained from food (Saragih 2020).

However, Agustina et al research with adolescent respondents aged 15 to 17 years found an increase in consumption of fast food, sweets, and fatty foods before Covid-19 from 57.0\% increased to $74.8 \%$. This needs attention because fast food, sweets, and fatty foods are low in micronutrients (minerals and vitamins) so it will increase the risk of decreased endurance and facilitate the transmission of Covid-19 (Agustina, Hardy, and Pristya 2021)

The phenomenon of changing food consumption patterns of Indonesian people is interesting to discuss. Because, in contrast to research conducted by some researchers in other countries, such as in Italy, Germany, Qatar, and Latin America, it turns out that the changes that occur are not the same pattern for all groups of people. And based on research from Azrimaidaliza et al, there is no significant relationship between knowledge and attitudes with respondents' behavior regarding COVID-19 and prevention efforts, especially in improving immunity.

Although respondents' knowledge belongs to the good category, there are still those who behave badly in efforts to prevent Covid-19, in this case, it means not complying with the recommendations of health protocols from the government. Although, still the largest percentage of respondents' poor behavior regarding COVID-19 and prevention efforts, in particular, improving the immunity of the body is indeed in the knowledgeable less, meaning that can not answer questions with a good score on the questionnaire given. However, respondents who had a considerable increase in food consumption, namely 2,421 times to behave to prevent COVID-19, with varying levels of knowledge. The results of the analysis showed that respondents made preventive efforts against COVID-19 through increased immunity. (Azrimaidaliza, Khairany Yasirly, and Putri Rahmi 2021).

The covid-19 pandemic in Indonesian society significantly affects food consumption patterns. Broadly speaking, changes in dietary consumption patterns in Indonesian society, are not influenced by the level of education. For example, even though the respondent's knowledge belongs to the good category, there are still those who behave badly in efforts to prevent Covid-19, in this case, it means 
E-ISSN: 2808-5361

http://e-journal.fkmumj.ac.id/
Proceeding The First

Muhammadiyah

Internasional- Public Health

and Medicine Conference

not complying with the recommendations of health protocols from the government. Although, still the largest percentage of respondents' poor behavior regarding COVID-19 and prevention efforts in particular increase body immunity is indeed in the knowledgeable less. It is recorded that there is a considerable increase in food consumption, which is 2,421 times to behave to prevent COVID-19, with varying levels of knowledge.

\section{CONCLUSION AND SUGGESTIONS}

Pandemic covid-19 in Indonesian society affects food consumption patterns, namely, in the adult group, the consumption of vegetables, fruit, and spices increased. While in adolescence, consumption of sweets and fast food increases.

Changes in food consumption patterns in Indonesian society occurred significantly. In adolescents aged 15 to 17 years, there was an increase in consumption of fast food, sweets, and fatty foods before Covid-19 from 57.0\% to $74.8 \%$. In the adult age group, the tendency of changes leads to a healthy diet in a personal effort to prevent exposure to Covid-19.

This change in the diet affects immunity. A healthy diet increases immunity and reduces the potential for contracting covid-19.

Changes in different diets require a customized approach to community nutrition fulfillment programs. It is necessary to create a program to raise awareness among young people to implement a healthy diet, and a program to support the consistency of healthy diets that have been formed in the community due to the covid-19 pandemic.

The next expected impact is that the level of public health will rise, the disease incidence in the community will decrease, and the health costs that must be borne by the government and the community can be suppressed.

\section{REFERENCES}

Agustina, Agustina, Fathinah Ranggauni Hardy, and Terry Y. R. Pristya. 2021. "Analisis Perbedaan Konsumsi Gizi Seimbang Sebelum Dan Pada Masa Covid-19 Pada Remaja.” JURNAL ILMIAH KESEHATAN MASYARAKAT: Media Komunikasi Komunitas Kesehatan Masyarakat 13(1):7-15. doi: 10.52022/jikm.v13i1.158.

Azrimaidaliza, Khairany Yasirly, and Putri Rahmi. 2021. "Pengetahuan, Sikap, Dan Perilaku Gizi Keluarga Dalam Meningkatkan Imunitas.” Jurnal Ilmiah Kesehatan 20(1):40-44. doi: 10.33221/jikes.v20i1.883.

Belén Ruíz-Roso, María, Patricia De Carvalho Padilha, Diana C. Matilla-Escalante, Paola Brun, Natalia Ulloa, Diofanor Acevedo-Correa, Wilza Arantes, Ferreira Peres, Miquel Martorell, Thais Rangel, Bousquet Carrilho, Letícia De Oliveira Cardoso, Fernanda Carrasco-Marín, Katherine Paternina-Sierra, María-Carmen Lopez De Las Hazas, Jhon E. Rodriguez-Meza, 
E-ISSN: 2808-5361 http://e-journal.fkmumj.ac.id/
Proceeding The First Muhammadiyah Internasional- Public Health and Medicine Conference

Luisa F. Villalba-Montero, Giulia Bernabè, Anthony Pauletto, Xhoajda Taci, Richar Cárcamo-Regla, J. Alfredo Martínez, Alberto Dávalos, D. A. Co, and J. E. Co. 2020. "Changes of Physical Activity and Ultra-Processed Food Consumption in Adolescents from Different Countries during Covid-19 Pandemic: An Observational Study." Nutrients 12(2289):1-13. doi: 10.3390/nu12082289.

ben Hassen, Tarek, Hamid El Bilali, and Mohammad S Allahyari. 2020. "Impact of COVID-19 on Food Behavior and Consumption in Qatar.” Sustainability. DOI: 10.3390/su12176973.

Junaidi, Alfia. 2020. "Pertimbangan Penyesuaian Langkah-Langkah Kesehatan Masyarakat Dan Sosial Dalam Konteks COVID-19.” World Health Organization (April):1-7.

Mayasari, Dewi, Dias Satria, and Iswan Noor. 2018. "Analisis Pola Konsumsi Pangan Berdasarkan Status IPM Di Jawa Timur.” Jurnal Ekonomi Dan Pembangunan Indonesia 18(2):191-213. doi: 10.21002/jepi.v18i2.801.

Miranti, Astari, and Yusman Syaukat. 2016. "POLA KONSUMSI PANGAN RUMAH TANGGA DI PROVINSI JAWA BARAT Household Food Consumption Patterns in West Java Province.” Jurnal Agro Ekonomi 34(1):67-80. doi: 10.21082/jae.v34n1.2016.67-80.

Robertson Sally. 2021. "COVID-19 Pandemic Negatively Impacts Eating Behaviors.” News Medical Life Science. Retrieved April 19, $2021 \quad$ (https://www.newsmedical.net/news/20210114/COVID-19-pandemic-negatively-impacts-eatingbehaviors.aspx).

Saputri, Rahmadya, Lily Arsanti Lestari, and Joko Susilo. 2016. Pola Konsumsi Pangan Dan Tingkat Ketahanan Pangan Rumah Tangga Di Kabupaten Kampar Provinsi Riau. Vol. 12.

Saragih, Frederic. 2020. “GAMBARAN KEBIASAAN MAKAN MASYARAKAT PADA MASA PANDEMI COVID-19 (Description of Community Food Habits in the Covid-19 Pandemic Period).” Jurnal Kesehatan.

Scarmozzino, Federico, and Francesco Visioli. 2020. "Covid-19 and the Subsequent Lockdown Modified Dietary Habits of Almost Half the Population in an Italian Sample." Foods 9(5). DOI: $10.3390 /$ foods 9050675 .

Sumarmi, Sri. 2020. "Kerja Harmoni Zat Gizi Dalam Meningkatkan Imunitas Tubuh Terhadap Covid19: Mini Review Harmonity of Nutrients to Improve Immunity Against Covid-19: A Mini Review." Amerta Nutrition 413:250-56. doi: 10.2473/amnt.v4i3.2020.

Wakhudin, Romadlon Fauzan, Siregar Juliandi, and Firmansyah. 2020. "COVID-19 DALAM RAGAM TINJAUAN PERSPEKTIF." in MBridge Press, edited by H. Santoso Didik and Santosa Awan. Yogyakarta: MBridge Press. 